\title{
Description of surgical technique in rabbit cannulation for obtaining cecal content
}

\author{
Descripción de una técnica quirúrgica de canulación en conejos para la obtención \\ de contenido cecal
}

\author{
M Anaya-Lira ${ }^{\mathrm{a}}$, C Gutiérrez-Olvera ${ }^{\mathrm{b}}$, AM Ducoing-Watty ${ }^{\mathrm{c}}$, F Jiménez-Gómez ${ }^{\mathrm{d}}$ \\ aDepartamento de Etología, Fauna Silvestre y Animales de Laboratorio, Facultad de Medicina Veterinaria y Zootecnia, \\ Universidad Nacional Autónoma de México, México. \\ bepartamento de Nutrición Animal y Bioquímica, Facultad de Medicina Veterinaria y Zootecnia, \\ Universidad Nacional Autónoma de México, México. \\ 'Departamento de Genética y Bioestadística, Facultad de Medicina Veterinaria y Zootecnia, \\ Universidad Nacional Autónoma de México, México. \\ ${ }^{\mathrm{d}}$ Departamento de Investigación Quirúrgica, Hospital Juárez de México, México.
}

\begin{abstract}
RESUMEN
Para conocer cómo se utilizan los diferentes nutrimentos en el sistema digestivo se han desarrollado técnicas de fistulación e implantación de cánulas utilizables en la mayor parte de los animales domésticos, pero en el caso de los conejos, las descripciones de estos procedimientos son escasas e incompletas. Este estudio tiene como objetivo describir la técnica quirúrgica de canulación utilizando una cánula de silicón grado médico en fijación lateral colocada en $13^{\mathrm{a}}$ asa cecal para obtener contenido cecal. Para ello, se utilizaron 20 conejos, observándose que la fijación lateral de la cánula y la utilización de cánula de silicón en $13^{\text {a }}$ asa cecal permite fácilmente la recolección de la muestra sin necesidad de suspender al animal, colocado en una hamaca.
\end{abstract}

Palabras clave: canulación, decimotercer asa cecal, conejos.

\section{SUMMARY}

Fistulae and cannula placement techniques have been developed in the majority of domestic animals to know how the various nutrients are used in the digestive system, nevertheless, in rabbits, the descriptions of these procedures are few and incomplete. The aim of this study was to describe a surgical cannulation technique, using a medical grade lateral silicone cannula fixed at the $13^{\text {th }}$ cecal loop in order to obtain cecal content; for this purpose 20 rabbits were used. It was found that lateral fixation of the cannula using a silicon cannula at the $13^{\text {th }}$ cecal loop allows easy sample collection without suspending the animal, placed in a hammock.

Key words: cannulae, thirteenth cecal loop, rabbits.

\section{INTRODUCTION}

Rabbits are herbivores with a digestive system that is highly adapted to the ingestion of fiber. Close to $80 \%$ of the ingested food is contained in the stomach and in the cecum, the latter has an important role in the digestion of fiber since it is the place where occurs an important level of bacterial activity that is responsible for digesting between 25 and $50 \%$ of the organic matter (Bellier et al 1995, 1996, Gidenne and Perez 1996). Volatile fatty acids are obtained as a byproduct of fiber fermentation, as well as B-complex vitamins and high biological value protein synthesis (Cheeke 1987). In order to study how the different nutrients are used in the digestive system of herbivores, an easy and permanent access is needed to compartments

Accepted: 13.08.2015.

* Circuito Interior s/n Ciudad Universitaria, CP. 04510 México, DF; adriana.ducoing@gmail.com where the most relevant and specific digestion activities are carried out.

In the majority of domestic animals several fistulae and cannula placement techniques have been developed that are adequate for the purpose of placing or extracting samples and carry out several types of evaluations. Nevertheless, in the case of rabbits the description of this procedures are few and incomplete (Carman and Waynforth 1984, Cabrera et al 2000, Parker and McMillan 1976, Gidenne 1992, Jehl and Gidenne 1996, Gidenne et al 1998). Even though there has been reports of cannulation in the cecum and 13th cecal loop (Hernández and Cobos 2001, Blas et al 2003), currently there is no information on the cannulation technique and effectiveness of the cannulas to obtain and evaluate cecal content in vivo.

Most of the studies carried out in rabbit's cecal fermentation use material that is taken from recently slaughtered animals, extrapolating the results to an in vivo situation (Gidenne 1992). Thus, in order to obtain cecal material samples directly from the animal, it is important to place 
cannulas at this level, with a minimal impact in the normal digestive tract functioning (Gidenne et al 2002, Hernández and Cobos 2001).

Placement of cannulae at the cecal level allows direct studies on the microflora present in the cecum and on the fermentation that is carried out by these microorganisms. It also allows the evaluation of the production of several metabolites such as ammonia and volatile fatty acids (that are produced and absorbed in the cecum), as well as the presence of vitamins and the $\mathrm{pH}$ changes generated by the various components of the diet (Cabrera et al 2000).

The effects of diet, age and general condition of the animal on the digestibility of amino acids and other nutrients can be shown using cannulae in the gastrointestinal tract, nd it also allows the tracking of enzyme products and inoculums in the digestive tract to directly asses its performance. Another important advantage provided by cannulae placement is the possibility of taking several samples from the same animal at different times and for a long time (Harmon and Richards 1997).

In a previous study, Anaya et al (2013) evaluated the use of different types of cannulas and the attachment site (lateral and ventral), for cecal contents without disrupting the posterior gut and welfare of rabbits; lateral fixation was that yielded cecal contents during the period of the study, which represents an alternative for conducting nutritional studies without slaughter of animals.

Therefore, this study aims to provide a description of the surgical cannulation technique.

\section{MATERIAL AND METHODS}

Eleven New Zealand adult female rabbits ( $>4$ months old with average weight of $2.42 \mathrm{~kg}$ ) and nine young female New Zealand rabbits ( 2 months old with average weight of $1.6 \mathrm{~kg}$ ), using a medical grade silicone cannula (figure 1) at the 13th cecal loop were used in this study. All the handling procedures complied with the requirements indicated by the Institutional Committee for the Care and Use of Experimental Animals (CICUAE- FMVZ-UNAM con base en la Norma Oficial Mexicana NOM-062-ZOO-1999).

\section{SURGICAL PROCEDURE}

Patient preparation. Surgical procedures were carried out in the operating theatre of the Surgical Research Unit of the Juarez Hospital, Mexico using the required asepsis conditions and specific previously sterilized instruments.

Animals were kept in fasting conditions for 12 hours, sedated by intramuscular administration (I.M.) of Xylazine at a dose of $5 \mathrm{mg} / \mathrm{kg}$ of weight and then anesthetised using Ketamine I.M. at a dose of $30 \mathrm{mg} / \mathrm{kg}$ of weight. The approximation area (linea alba) and the cannula placement area were depilated and disinfected (iodine povidone), then lidocaine (2\%) was infiltrated locally into the cutaneous and muscular planes in a ring fashion.

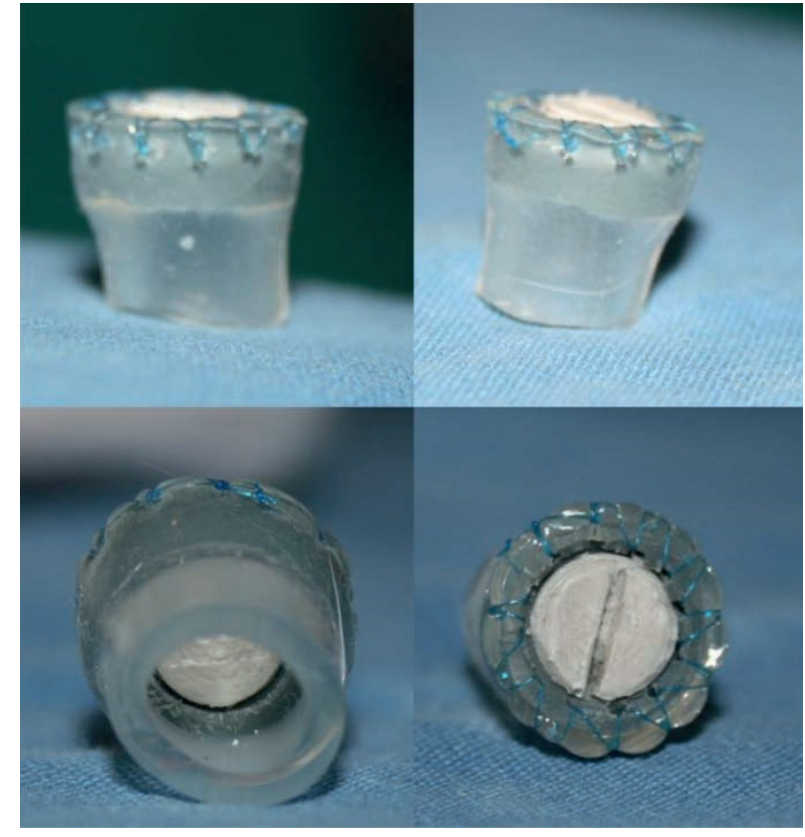

Figure 1. Flexible medical grade silicone cannula with threaded PVC cap; internal disk diameter $0.8 \mathrm{~cm}$, external disk diameter $1.3 \mathrm{~cm}$, diameter of the closing cap $0.8 \mathrm{~cm}$, useable diameter of the cannula opening $0.8 \mathrm{~cm}$, total thickness of the cannula $1.3 \mathrm{~cm}$.

Cánula flexible de silicón grado médico con tapón de PVC con rosca; cuyas medidas son: Diámetro del disco interno 0,8 cm, Diámetro del disco externo $1,3 \mathrm{~cm}$, diámetro de la tapa de cierre $0,8 \mathrm{~cm}$, diámetro de la abertura útil de la cánula $0,8 \mathrm{~cm}$, espesor total de la cánula $1,3 \mathrm{~cm}$.

Surgical method. Animals were operated upon in a dorsal decubitus position. Once they reached the desired unconsciousness and local anesthesia levels, a $5 \mathrm{~cm}$ long straight incision was made on the skin using a scalpel and later the subcutaneous plane was opened using blunt dissection forceps to expose the linea alba. Access to the abdominal cavity was achieved by making a surgical incision on said line and the organ to be cannulated was located (figure 2).

Lateral attachment of the cannulae was carried out on the central point of a triangle formed by the thirteenth costal arch, the edge of the transverse process of the fifth lumbar vertebra and the coxofemoral joint attachment of the cannula on the thirteenth cecal loop was located on the left flank. Then, a $1.5 \mathrm{~cm}$ long horizontal incision of the skin was made, and the corresponding abdominal muscular planes (abdominal external oblique, abdominal internal oblique) and transverse fascia were dissected using blunt dissection scissors. Similarly, the peritoneum was opened and the organ was slightly exposed $(<$ $1 \mathrm{~cm}$ ) (figure 3).

In order to attach the compartment to the skin in its definitive position a non-perforating suture was carried out using 5-0 polypropylene suture with a "U" stitch that went through skin, peritoneum and compartment 

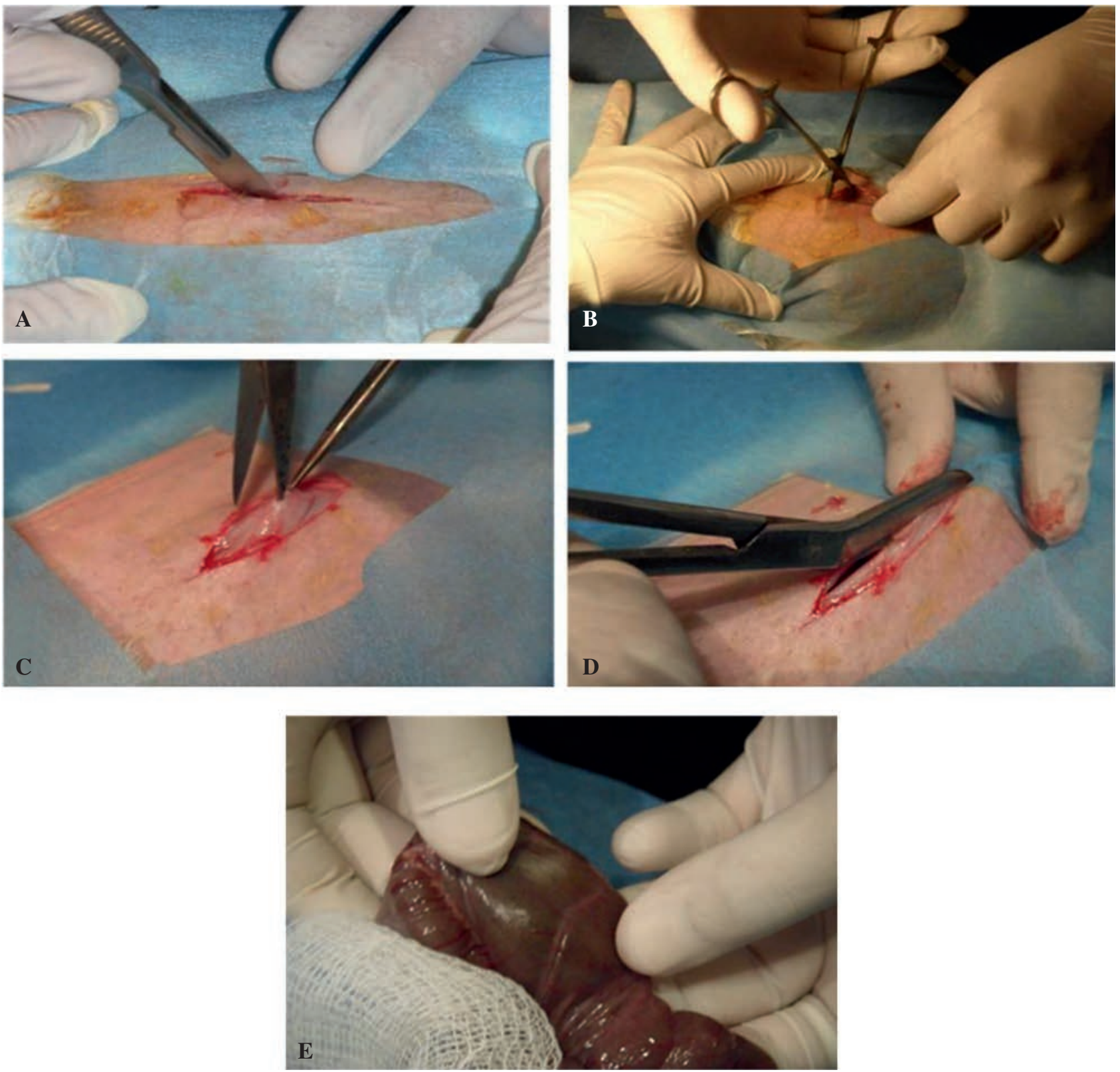

Figure 2. A), B), C), D) Surgical approach and identification of cecum; E) cecum.

A), B), C), D) Abordaje quirúrgico e identificación del ciego; E) ciego.

wall that exited through the peritoneum and skin (compromising the visceral peritoneum and musculature without entering mucosa), taking care of maintaining the normal position of the compartment in relation to the incision on the abdominal wall. Afterwards the cannula was placed and made to pass through the incision of the organ. In order to attach the cannula to the organ, muscle and skin in its definitive position a right continuous simple suture was done using 5-0 polypropylene suture that perforated each plane and the cannula to ensure air-tight sealing of the abdominal cavity. Once the attachment of the cannula to the organ and to the muscle plane was concluded access to the organ lumen through the cannula was corroborated (figure 4). After this stage the linea alba was closed using anchored stitches and Cushing's suture pattern was used on the subcutaneous tissue, both were done using 3-0 polyglycolic acid suture. Skin was closed using anchored stitches using 3-0 nylon suture. Figure 5 shows a cannula placed in one of the subjects.

Postsurgical treatment included the administration of IM antibiotics during 6 days and IM anti-inflammatory drugs during 3 days. Stitches on the midline were removed on the seventh day. 

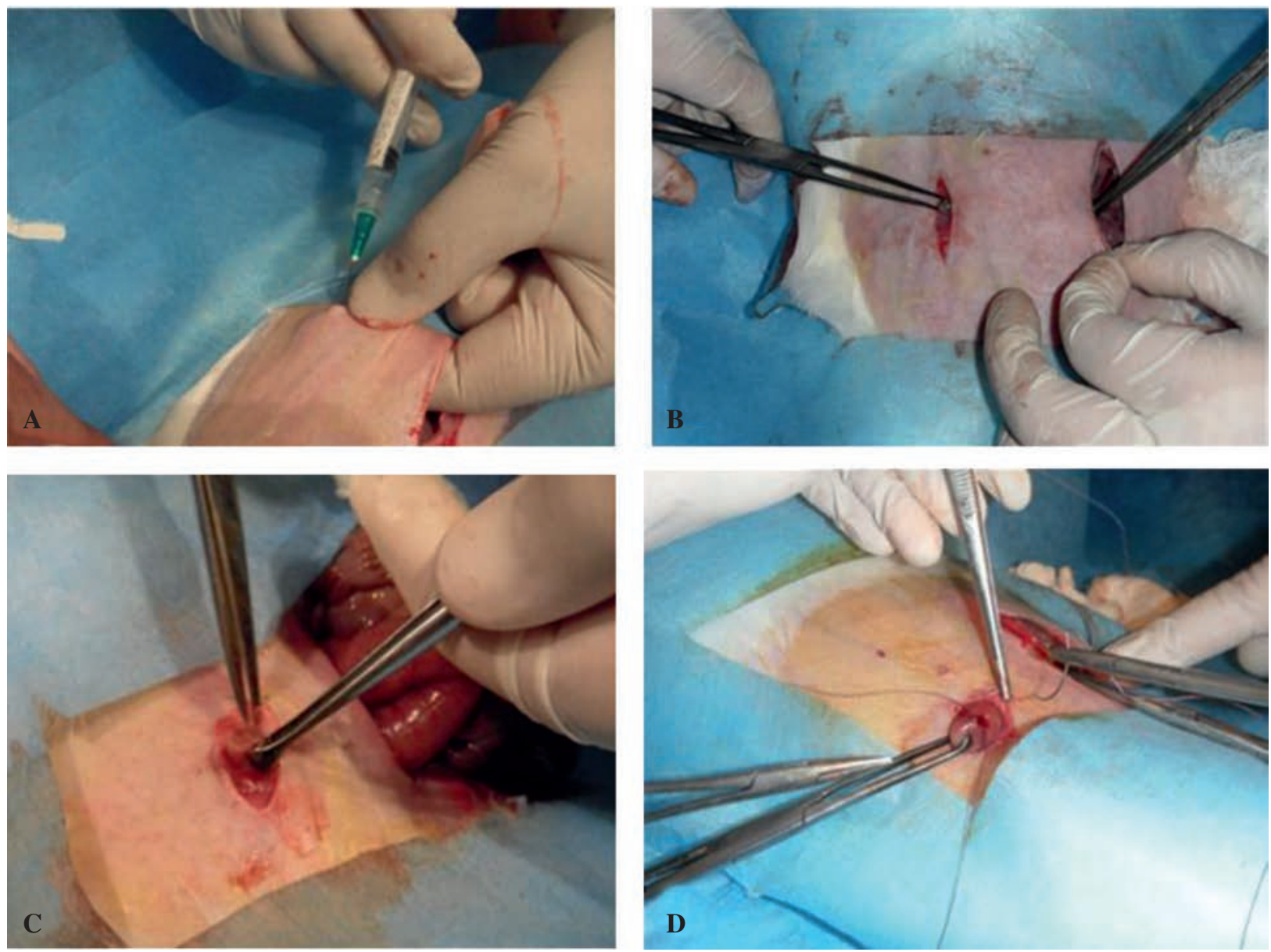

Figure 3. A), B), C), D) Lateral incision; C) exposure of the organ; D) attachment of the organ. A), B), C), D) Incisión lateral; C) exposición del órgano; D) fijación del órgano.

\section{RESULTS AND DISCUSSION}

All rabbits showed a good response to the entire surgical procedure as none showed postsurgical complications. Their sedation and anesthesia levels were achieved between 10 to 20 minutes after administration with an adequate depth. No animal showed hemorrhages of importance when the muscular planes were dissected. The cannulae adapted well to their corresponding fistulae without leakage of contents.

In this study, it was found that the lateral attachment of the cannula technique (for adults and young animals) facilitates handling for obtaining the simple. This occurred even though the surgical technique is more complex and requires a skilled surgeon and more time for the procedure. However, no negative effects (like daily weight gain) were detected in animal development during the period of post-surgical recovery (Martínez and Valdés 1997), which lasted 17 days.

It can be concluded that the placement of the cannula in a lateral position easily allows the collection of cecal content sample without the need to suspend the animal in a hammock waiting for cecal content to be obtained by gravity, as described by Bellier et al (1995).

\section{ACKNOWLEDGEMENTS}

The authors would like to thank the support provided by the Programa de Apoyo a Proyectos de Investigación e Innovación tecnológica (PAPIIT) IN216309 and team of collaborators; they also thank the Hospital Juárez de México for providing the facilities of the Surgical Research Unit.

\section{REFERENCES}

Anaya LM, OC Gutiérrez, WA Ducoing, L Sanginés. 2013. Determinación in vivo de parámetros fermentativos de contenido cecal en conejos canulados por diferentes técnicas y la evaluación de éstas. Tesis Maestría, Facultad de Medicina Veterinaria y Zootecnia, Universidad Nacional Autónoma de México, Distrito Federal, México.

Bellier R, T Gidenne, M Vernay, M Colin. 1995. In vivo study for circadian variations of the cecal fermentation pattern in postweaned and adult rabbits. J Anim Sci 73,128-135.

Bellier R, T Gidenne. 1996. Consequences of reduced fibre intake on digestion, rate of passageand caecal microbial activity in the young rabbit. Br J Nutr 75, 353-363.

Blas E, L Falcao, T Gidenne, C Scapinello, V Pinheiro, AL García, R Carabaño. 2003. Interlaboratory study on ileal digestibility in rabbits: the effect of digesta collection time and a simplification of the procedure. World Rabbit Sci 11, 101-111.

Cabrera R, A López, S Morales. 2000. Fistulación y canulación permanente del compartimento 1 (Rumen) en Llamas (Lama glama). Arch Med Vet 32, 131-138. 

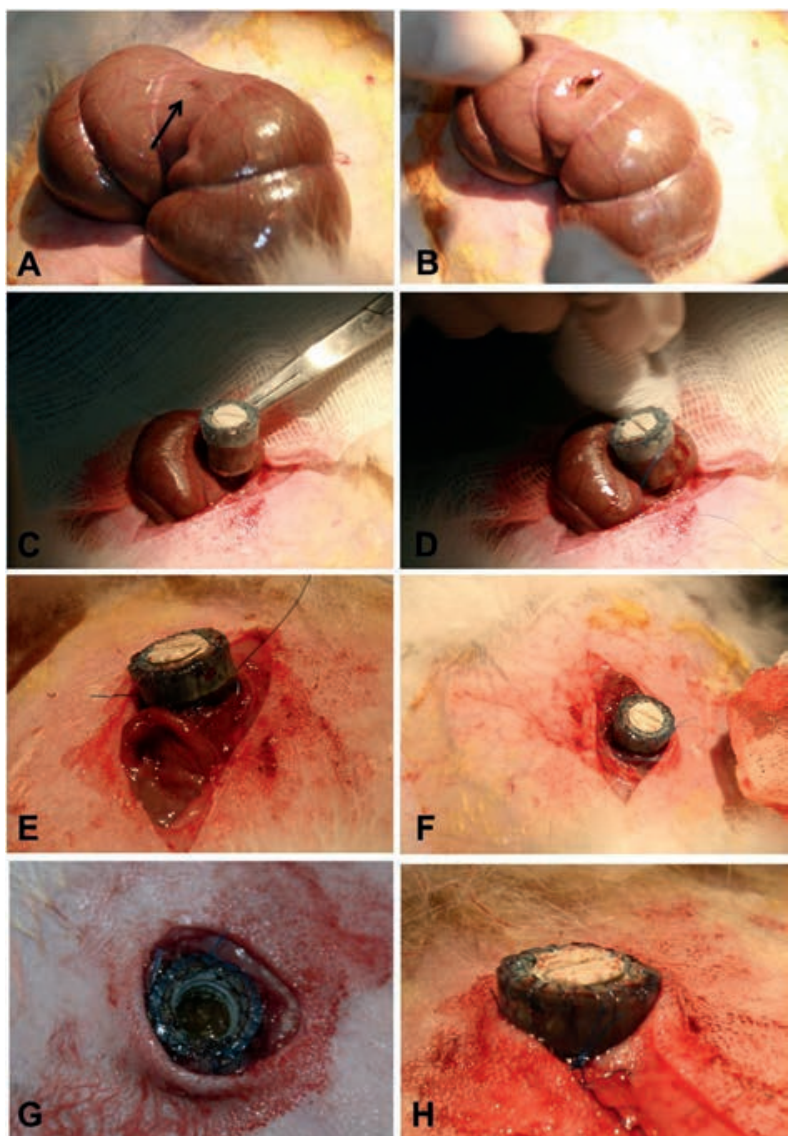

Figure 4. A) Incision of the organ; B) widening of the incision; C), D), E) placement and attachment of the cannula to the organ; G) Verification of the organ lumen access in which cecal content can be observed; F) attachment of the cannula to skin.

A) Incisión del órgano; B) ampliación de la incisión; C), D), E) colocación y fijación de la cánula al órgano; G) verificación del acceso a la luz del órgano donde se observa el contenido cecal; F) fijación de la cánula a la piel.

Carman RJ, WB Waynforth. 1984. Chronic fistulation and cannulation of the rabbit caecum. Lab Anim 18, 258-260.

Cheek PR. 1987. Carbohydrates and fiber. In: Cunha T (ed). Rabbit feeding and nutrition. Academic Press, Orlando, USA, Pp 83.

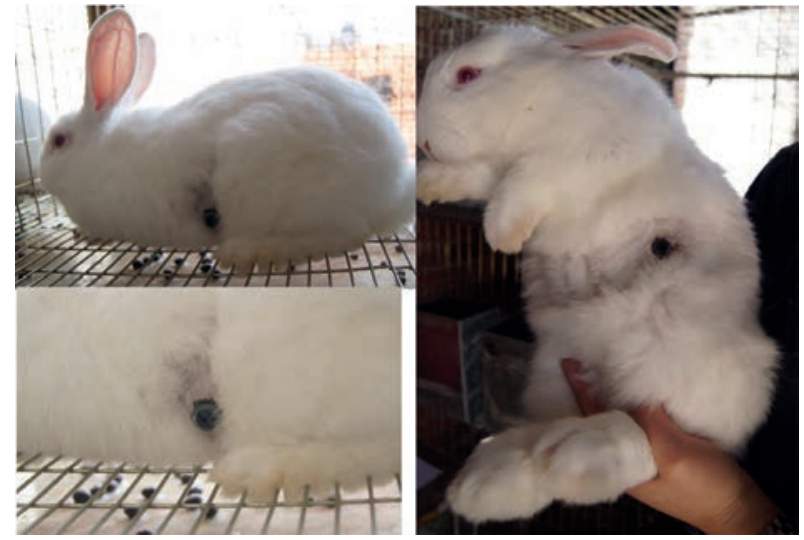

Figure 5. Rabbit with cannula.

Conejo con cánula.

Gidenne T.1992. Effect of fibre level, particle size and adaptation period on digestibility and rate of passage as measured at the ileum and in the faeces in the adult rabbit. Br J Nutr 67, 133-146.

Gidenne T, JM Perez. 1996. Apports de cellulose dans l'alimentation du lapin en croissance. I. Conséquences sur la digestion et le transit. Ann Zootech 45, 289-298.

Gidenne T, R Bellier, J Van Eys. 1998. Effect of the dietary fibre origin on the digestion and on the caecal fermentation pattern of the growing rabbit. Anim Sci 66, 509-517.

Gidenne T, N Jehl, M Segura, B Michalet-Doreau. 2002. Microbial activity in the caecum of the rabbit around weaning: impact of a dietary fiber deficiency and of intake level. Anim Feed Sci Tech 99, 107-118.

Harmon DL, CJ Richards. 1997. Considerations for gastrointestinal cannulations in ruminants. J Anim Sci 75, 2248-2255.

Hernández SD, PMA Cobos. 2001. Digestibilidad in vitro, población de bacterias celulolíticas y totales del apéndice cecal, ciego y colon del conejo. Tec Pecu Méx 39, 229- 236.

Jehl N, T Gidenne. 1996. Replacement of starch by digestible fibre in feed for the growing rabbit. 2. Consequences for microbial activity in the caecum and on incidence of digestive disorders. Anim Feed Sci Tech 61, 193-204.

Martínez DS, RO Vázquez, GR Valdés. 1997. Histocicatrización. In: Martínez S, Valdés R (eds). Cirugía bases del conocimiento quirúrgico. $2^{\mathrm{a}}$ ed. Mc Graw Hill Interamericana, México, Pp 221-230.

NOM-062-ZOO-1999. 1999. Especificaciones técnicas para la producción, cuidado y uso de los animales de laboratorio.

Parker DS, RT McMillan. 1976. The determination off volatile fatty acids in the caecum of the conscious rabbit. Br J Nutr 35, 365-371. 
